\title{
DISPARITAS REGIONAL PROVINSI SUMATERA BARAT DI ERA OTONOMI DAERAH
}

\author{
Regional Disparities of the West Sumatra Province in the Regional \\ Autonomy
}

\section{Syahrial ${ }^{1}$, Dedi Budiman Hakim² ${ }^{2}$, Yeti Lis Purnamadewi²}

Diterima: 9 Desember 2014 Disetujui :

\begin{abstract}
Abstrak: Kebijakan otonomi daerah sudah dilaksanakan sejak tahun 2001, namun pada tahun 2013 sebanyak 66.67 persen kabupaten di Sumatera Barat masih dikategorikan sebagai daerah tertinggal oleh Kementrian Pembangunan Daerah Tertinggal. Hal ini mengindikasikan masih terdapatnya ketimpangan yang sangat tinggi di Provinsi Sumatera Barat. Penelitian ini tidak hanya melihat ketimpangan antar wilayah, tetapi juga menganalisis dampak dari PDRB per kapita, pertumbuhan Indeks Pembangunan Manusia, dan Rasio Belanja Infrastruktur terhadap ketimpangan berdasarkan posisi perekonomian (pola dan struktur pertumbuhan ekonomi). Analisis data menggunakan Indeks Williamson dan regresi data panel tahun 2005 sampai 2012. Hasil analisis menunjukkan disparitas regional di Provinsi Sumatera Barat semakin meningkat. Secara simultan dan parsial tiga variabel bebas (PDRB per kapita, pertumbuhan Indeks Pembangunan Manusia, dan Rasio Belanja Infrastruktur) berpengaruh signifikan dan positif sebagai sumber utama disparitas regional di Provinsi Sumatera Barat.
\end{abstract}

\section{Kata Kunci: disparitas regional, otonomi daerah, Provinsi Sumatera Barat.}

\begin{abstract}
Regional autonomy policy has been implemented since 2001, but in 2013 as many as 66.67 percent of districts in West Sumatra still categorized as a relatively underdeveloped region by the Ministry of Development Underdeveloped regions. This indicates the occurrence of inequality considerable development in the Province of West Sumatra. This study not only examines the degree of inequality between regions, but also analyze the impact of GDRP per capita, the growth of the Human Development Index, and the Ratio of Infrastructure Expenditure against the inequalities based on economic position (the pattern and structure of economic growth). Analysis of the data use the Index Williamson and panel data regession from 2005 to 2012. The results showed disparity of regional development in the Provinces of West Sumatra increasing. Simultaneously and partially three independent variables (GDRP per capita, the growth of the Human Development Index, the Ratio of Infrastructure Expenditure) significant and positive influence as a major source of regional disparities in the Province of West Sumatra.
\end{abstract}

Key words: regional disparities, regional autonomy, the Province of West Sumatra

\footnotetext{
${ }^{1}$ Program Magister Sekolah Pascasarjana

Program Studi Ilmu Ilmu Perencanaan Pembangunan Wilayah dan Perdesaan, FEM IPB

${ }^{2}$ Program Studi Ilmu Ilmu Perencanaan Pembangunan Wilayah dan Perdesaan, FEM IPB
} 
Pendahuluan

Tujuan utama dari usaha-usaha pembangunan ekonomi selain menciptakan pertumbuhan yang tinggi, harus diikuti dengan pengurangan tingkat ketimpangan. Ketimpangan pembangunan antar wilayah merupakan aspek yang umum terjadi dalam kegiatan ekonomi suatu daerah. Ardani (1992) mengemukakan bahwa kesenjangan/ketimpangan antar daerah merupakan konsekuensi logis pembangunan dan merupakan suatu tahap perubahan dalam pembangunan itu sendiri. Ketimpangan ini pada dasarnya disebabkan oleh adanya perbedaan kandungan sumberdaya alam dan perbedaan kondisi geografis yang terdapat pada masing-masing wilayah. Akibatnya, kemampuan suatu daerah dalam mendorong proses pembangunan juga menjadi berbeda sehingga tidaklah mengherankan jika pada setiap daerah biasanya terdapat wilayah maju (development region) dan wilayah terbelakang (underdevelopment region). Terjadinya ketimpangan antar wilayah membawa implikasi terhadap tingkat kesejahteraan masyarakat antar wilayah sehingga aspek ketimpangan pembangunan antar wilayah mempunyai implikasi terhadap formulasi kebijakan pembangunan wilayah yang dilakukan oleh pemerintah daerah. Bose et al. (2005) mengemukakan bahwa tingkat pembangunan ekonomi menentukan keuangan publik optimal suatu wilayah.

Dilaksanakannya otonomi daerah dan desentralisasi pembangunan, maka pembangunan daerah, termasuk daerah terbelakang dapat lebih digerakkan karena ada wewenang yang berada pada pemerintah daerah dan masyarakat setempat. Dengan adanya kewenangan tersebut, maka aspirasi masyarakat untuk menggali potensi daerah akan lebih baik. Dengan demikian diharapkan proses pembangunan daerah secara keseluruhan akan dapat ditingkatkan dan secara bersamaan ketimpangan pembangunan antar wilayah akan dapat pula dikurangi (Sjafrizal, 2008).

Ketimpangan pendapatan antar wilayah menjadi fenomena penting yang masih terus perlu dikaji dan dianalisis karena sangat menentukan kebijakan yang dapat diambil pemerintah agar lebih terarah, serta berjalan dengan efektif dan efesien, di bawah kendala keterbatasan anggaran dan sumberdaya yang dapat digunakan dalam upaya peningkatan kesejahteraan masyarakat. Penelitian ini tidak hanya berusaha mengkaji tingkat ketimpangan antar wilayah, namun juga menganalisis dampak PDRB per kapita, pertumbuhan Indeks Pembangunan Manusia, dan Rasio Belanja Infrastruktur terhadap ketimpangan berdasarkan posisi perekonomian (pola dan struktur pertumbuhan ekonomi) suatu wilayah. Kekuatan yang dimiliki suatu wilayah diharapkan dapat meningkatkan perekonomian wilayah sekitarnya. Adanya pusat pertumbuhan suatu wilayah menjadi rangsangan pertumbuhan ekonomi wilayah sekitarnya.

Secara umum nilai PDRB kabupaten/kota di Sumatera Barat mengalami peningkatan dari tiap tahunnya. Namun jika dilihat dari sebaran PDRB per kabupaten/kota memiliki variasi yang cukup tinggi. Hanya beberapa kabupaten/kota yang memiliki PDRB lebih tinggi dari rata-rata PDRB Sumatera Barat yaitu Padang, Agam, Solok, Tanah Datar, Pasaman Barat dan Kabupaten 50 Kota. Padang menjadi kota yang memiliki PDRB paling tinggi di setiap tahunnya dan sangat timpang jika dibandingkan dengan kabupaten/kota lain. Pada tahun 2012, PDRB tertinggi dimiliki oleh Kota Padang sebesar Rp 13.637,51 miliar disusul Kabupaten Agam sebesar Rp 3.503,88 miliar dan PDRB terendah didapat oleh Kota Padang Panjang Rp 474,57 miliar. Pada tahun yang sama, PDRB per kapita tertinggi dimiliki oleh Kota Padang sebesar 15,96 juta rupiah dan terendah di Kabupaten Solok Selatan Rp 4,98 juta.

Pertumbuhan ekonomi Sumatera Barat tahun 2012 berkisar di angka 6,35 persen, dimana pertumbuhan ekonomi tertinggi dimiliki oleh Kabupaten Agam dan Kota Payakumbuh sebesar 6,82 persen dan pertumbuhan ekonomi terendah dimiliki Kabupaten Kepulauan Mentawai sebesar 5,25 persen (BPS, 2013). Bervariasinya nilai PDRB, PDRB per kapita dan pertumbuhan ekonomi ini memicu terjadinya ketimpangan antar kabupaten/kota di Provinsi Sumatera Barat.

Keberhasilan pembangunan seharusnya tidak cukup dilihat dan diukur dari pembangunan di bidang ekonomi saja tetapi juga perlu melibatkan aspek pembangunan manusia. Indeks Pembangunan Manusia (IPM) harus memperoleh tempat yang istimewa dalam program pembangunan, karena tidak ada suatu wilayah yang mampu berkembang dan tumbuh secara berkelanjutan hanya dengan mengandalkan sumber daya alam (SDA) yang dimilikinya. Perbaikan kesenjangan bisa dicapai dengan melakukan investasi pada pembangunan manusia, baik dalam 
peningkatan akses dan kualitas di bidang pendidikan maupun peningkatan akses, kualitas dan layanan di bidang kesehatan.

Meskipun secara umum terjadi peningkatan IPM Sumatera Barat dari tahun 2004 sebesar 70,52 menjadi 70,74 pada tahun 2012, namun ditingkat kabupaten/kota angka IPM sangat bervariasi. Daerah yang memiliki perkembangan IPM lebih tinggi dibandingkan rata-rata IPM Sumatera Barat adalah Kota Bukittinggi, Kota Padang, Kota Padang Panjang, Kota Payakumbuh, Kota Solok, Kota Sawahlunto, Kota Pariaman, Kabupaten Tanah Datar, dan Kabupaten Agam Pada tahun 2012 nilai IPM tertinggi dimiliki oleh Kota Bukittinggi dengan nilai 79,07 dan terendah dicapai oleh Kabupaten Kepulauan Mentawai dengan IPM 69,26.

Salah satu permasalahan ketimpangan wilayah adalah persoalan daerah tertinggal. Berdasarkan data dari Kementrian Pembangunan Daerah Tertinggal Republik Indonesia tahun 2013, sebanyak 8 kabupaten dari 12 kabupaten yang ada di Sumatera Barat termasuk kategori daerah tertinggal yaitu Kepulauan Mentawai, Pesisir Selatan, Solok, Sijunjung, Padang Pariaman, Solok Selatan, Dharmasraya, dan Pasaman Barat. Kondisi seperti ini menempatkan Sumatera Barat sebagai provinsi kedua di Sumatera yang memiliki daerah tertinggal terbanyak setelah D.I Aceh yang memiliki kabupaten tertinggal sebanyak 12 kabupaten.

Upaya meminimalisir dampak negatif ketimpangan wilayah, pemerintah melakukan beberapa kebijakan antara lain dengan meningkatkan jumlah alokasi belanja infrastruktur. Peningkatan realisasi belanja infrastruktur diharapkan dapat menciptakan spread effect untuk pembangunan wilayah sekitar dengan memperlancar akses dan aktivitas perekonomian. Pertumbuhan suatu wilayah diharapkan dapat menjadi rangsangan pertumbuhan ekonomi wilayah sekitarnya. Terjadi peningkatan realisasi belanja infrastruktur di Provinsi Sumatera Barat dari waktu ke waktu. Pada tahun 2004 realisasi belanja infrastuktur sebesar Rp 90,410.96 juta rupiah dan meningkat pada tahun 2012 menjadi Rp 645,613.55 juta rupiah. Peningkatan realisasi belanja infrastuktur ini diharapkan dapat membantu mengurangi derajat ketimpangan antar wilayah di Sumatera Barat.

Sehubung dengan hal telah disebutkan di atas, maka yang menjadi pertanyaan penelitian ini adalah: (1) Bagaimana perkembangan tingkat ketimpangan pembangunan antarwilayah di Provinsi Sumatera Barat Barat di era otonomi daerah ?; (2) Apakah PDRB per kapita, pertumbuhan IPM dan Rasio Belanja Infrastruktur berpengaruh terhadap ketimpangan antar wilayah di era otonomi di Provinsi Sumatera Barat?

Penelitian ini bertujuan untuk: (1) Mengkaji perkembangan tingkat ketimpangan pembangunan antar wilayah di Provinsi Sumatera Barat Barat di era otonomi daerah; (2) Menganalisis dampak PDRB per kapita, pertumbuhan IPM dan Rasio Belanja Infrastruktur terhadap ketimpangan antar wilayah di era otonomi di Provinsi Sumatera Barat.

\section{Metode Penelitian}

Penelitian ini menggunakan pendekatan deskriptif dan kuantitatif. Analisis deskriptif digunakan untuk menjelaskan struktur ekonomi di Provinsi Sumatera Barat. Pendekatan kuantitatif menggunakan teknik ekonometrik.

Jenis data yang digunakan dalam penelitian ini adalah data sekunder yang bersumber dari publikasi Badan Pusat Statistik (BPS) Pusat, BPS Provinsi Sumatera Barat, Dinas Pengelolaan Keuangan Daerah Provinsi Sumatera Barat dan data dari Kementrian Pembangunan Daerah Tertinggal Republik Indonesia. Pengumpulan data sekunder dilakukan dengan cara studi kepustakaan dan studi dokumen. Dari pengumpulan data sekunder tersebut maka diperoleh dua jenis data, yaitu data antar waktu (time series) dan data antar individu (cross section).

Data time series adalah data yang dikumpulkan dari waktu ke waktu terhadap suatu kabupaten/kota yang terdiri dari data 8 tahun yaitu tahun 2005 - 2012. Data cross section adalah data yang dikumpulkan dalam satu waktu terhadap banyak individu (kabupaten/kota), dalam kajian ini terdiri dari 19 kabupaten/kota di Provinsi Sumatera Barat.

Djodjohadikusumo (1994) menjelaskan bahwa bangunan ekonomi merupakan suatu proses transformasi yang ditandai oleh perubahan struktur perekonomian, yaitu perubahan pada landasan kegiatan ekonomi maupun pada kerangka susunan ekonomi masyarakat yang 
bersangkutan. Dengan demikian antara perubahan struktur dan pertumbuhan memiliki keterkaitan yang sangat erat.

Tabel 1. Matriks Tipologi Klassen

\begin{tabular}{|c|c|c|}
\hline 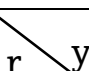 & yi $>$ y & yi $<y$ \\
\hline ri $>r$ & $\begin{array}{l}\text { Pendapatan tinggi dan pertumbuhan } \\
\text { tinggi } \\
\text { (Daerah cepat maju dan cepat tumbuh) }\end{array}$ & $\begin{array}{l}\text { Pendapatan rendah dan pertumbuhan tinggi } \\
\text { (Daerah berkembang cepat) }\end{array}$ \\
\hline $\mathrm{ri}<\mathrm{r}$ & $\begin{array}{l}\text { Pendapatan tinggi dan pertumbuhan } \\
\text { rendah } \\
\text { (Daerah cepat maju tapi tertekan) }\end{array}$ & $\begin{array}{l}\text { Pendapatan rindu dan pertumbuhan rendah } \\
\text { (Daerah relatif tertinggal) }\end{array}$ \\
\hline $\begin{array}{l}\text { Keterar } \\
\text { r: } \\
\text { y: } \\
\text { r: } \\
\text { y: }\end{array}$ & $\begin{array}{l}\text { rata pertumbuhan ekonomi provinsi } \\
\text { rata PDRB per kapita provinsi } \\
\text { mbuhan ekonomi kabupaten/kota yang diamati } \\
\text { s per kapita kabupaten/kota yang diamati }\end{array}$ & \\
\hline
\end{tabular}

Struktur ekonomi suatu wilayah juga dapat dijelaskan dengan menggunakan Analisis Tipologi Klassen yang pada dasarnya membagi daerah menjadi dua indikator utama, yaitu pertumbuhan ekonomi daerah dan pendapatan per kapita (PDRB per kapita) (Kuncoro 2004; Sjafrizal 2008).

Indeks Williamson merupakan indeks yang paling sering digunakan untuk mengukur disparitas antar wilayah (Sjafrizal 1997).

$$
\mathrm{I}_{\mathrm{w}}=\frac{\sqrt{\sum_{\mathrm{i}=1}^{\mathrm{n}}\left(\mathrm{y}_{\mathrm{i}}-\frac{3}{y^{2}}\right)^{\mathrm{2}\left(\mathrm{f}_{\mathrm{i}} / \mathrm{n}\right)}}}{y^{\prime}}, 0<\mathrm{I}_{\mathrm{w}}<1
$$

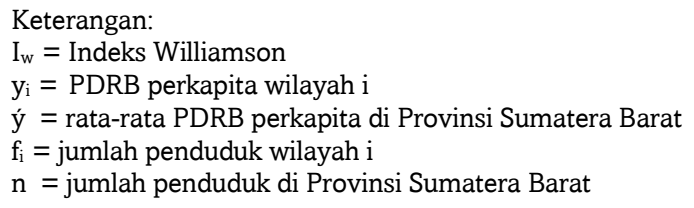

Analisis data panel terhadap variabel PDRB per kapita, pertumbuhan IPM dan Rasio Belanja Infrastruktur (RBI) untuk mengetahui sumber utama penyebab disparitas antar wilayah menggunakan pendekatan Fixed Effect Model (FEM):

$$
\mathrm{I}_{\mathrm{w}}=\beta_{0}+\beta_{1} \mathrm{Y}_{\mathrm{it}}+\beta_{2} \mathrm{IPM}_{\mathrm{it}}+\beta_{3} \mathrm{RBI}_{\mathrm{it}}+\mu_{i t}
$$

Dalam perhitungan regresi panel data semua variabel terikat dan variabel bebas dikelompokkan menjadi empat tipologi yang merujuk pada tipologi wilayah tahun 2005.

\section{Hasil Dan Pembahasan}

Disparitas Regional di Provinsi Sumatera Barat

Besarnya nilai PDRB per kapita masing-masing kabupaten/kota di Provinsi Sumatera Barat mempunyai variasi yang tinggi. Rata-rata nilai PDRB per kapita Sumatera Barat tahun 2004 2012 sebesar Rp 7,1 juta. Terdapat 8 kabupaten/kota yang memiliki nilai PDRB per kapita di atas rata-rata yaitu Kota Padang (Rp 13,03 juta), Kota Sawahlunto (Rp 8,90 juta), Kota Pariaman (Rp8,84 juta), Kota Bukittinggi (Rp 8,61 juta), Kota Solok (8,16 juta), Kota Padang Panjang (7,72 
juta), Kabupaten 50 Kota ( Rp7,58 juta) dan Kota Payakumbuh (Rp 7,13 juta). Sementara itu PDRB per kapita terendah dimilik oleh Kabupaten Solok Selatan (Rp 4,36 juta) (Gambar 1).

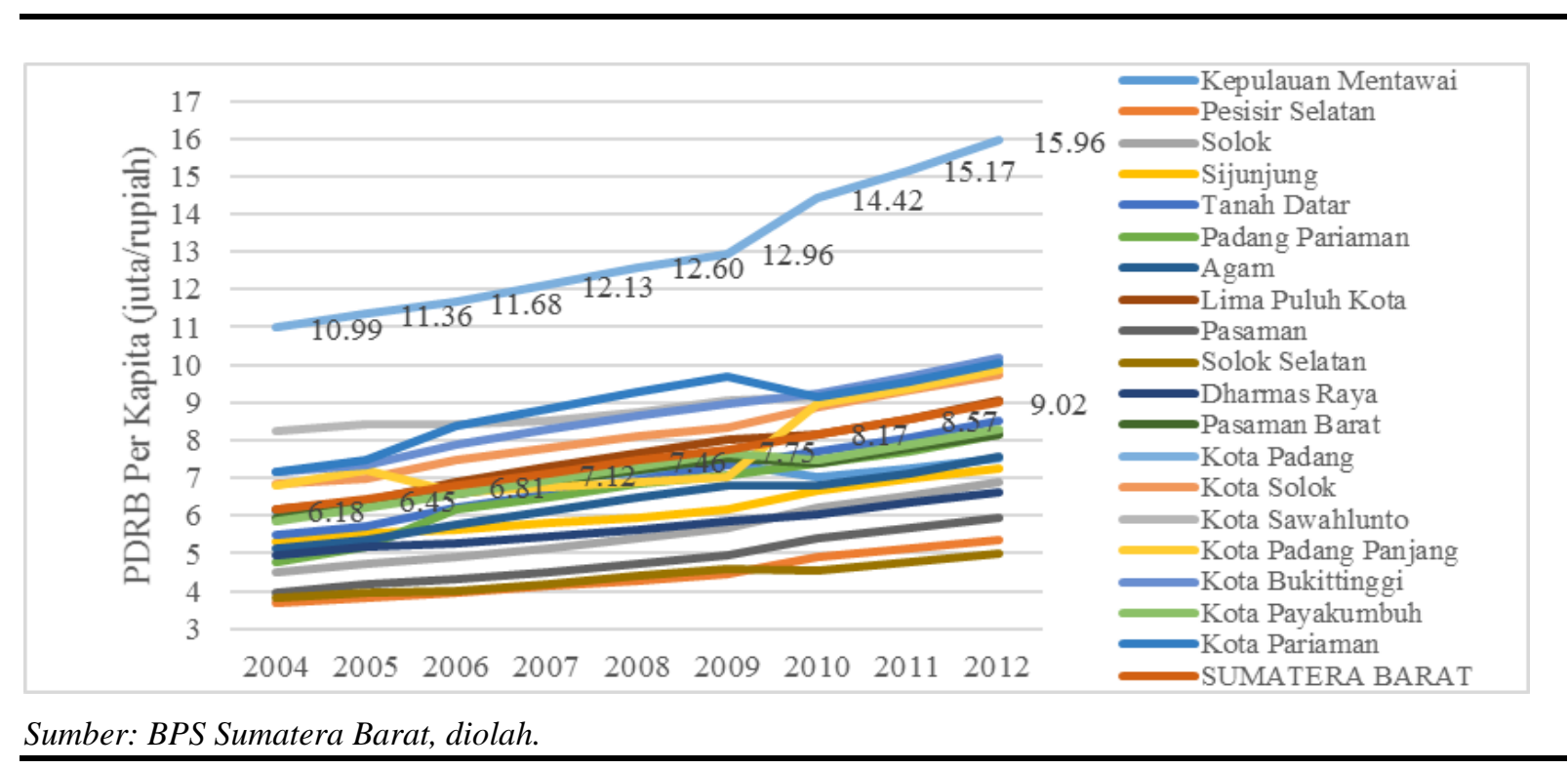

Gambar 1. PDRB Per Kapita Kabupaten/Kota Di Provinsi Sumatera Barat Tahun 2004 - 2012 ADHK 2000

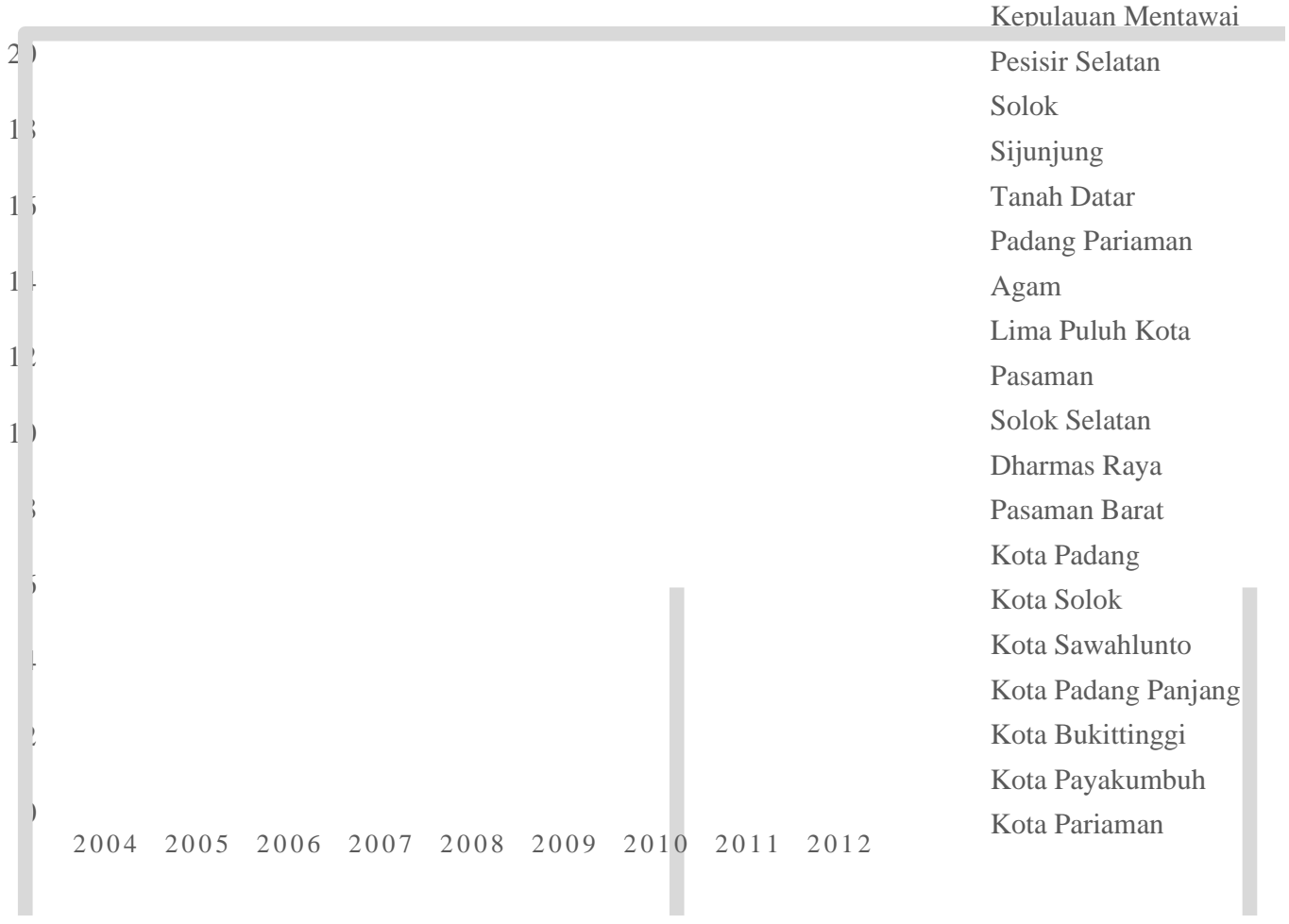

Sumber: BPS Sumatera Barat, diolah.

Gambar 2. Pertumbuhan ekonomi kabupaten/kota di Provinsi Sumatera Barat tahun 2004 - 2012 
Pertumbuhan ekonomi masing-masing kabupaten/kota di Sumatera Barat tahun 2004 2012 mengalami fluktuasi, namun secara umum berada pada rentang yang tidak jauh berbeda. Pada tahun 2006 pertumbuhan ekonomi tertinggi berada di Kabupaten Padang Pariaman sebesar 19,01 persen dan terendah di Kota Sawahlunto sebesar 1,04 persen. Pada tahun 2009 menunjukan bahwa hampir di semua kabupaten/kota mengalami penurunan pertumbuhan ekonomi (Gambar 2). Hal ini salah satunya disebabkan karena faktor alam, dimana pada tahun tersebut Provinsi Sumatera Barat dilanda bencana gempa bumi berkekuatan 7,6 SR (sangat kuat). Selain merusak infrastruktur seperti jalan, jembatan, bangunan publik seperti sekolah, perkantoran, pasar tradisional dan pemukiman penduduk, gempa juga mengakibatkan lahan pertanian rusak, sehingga hal ini menggangu dan menurunkan aktivitas ekonomi.

Tabel 2. Tipologi wilayah di Provinsi Sumatera Barat Tahun 2005

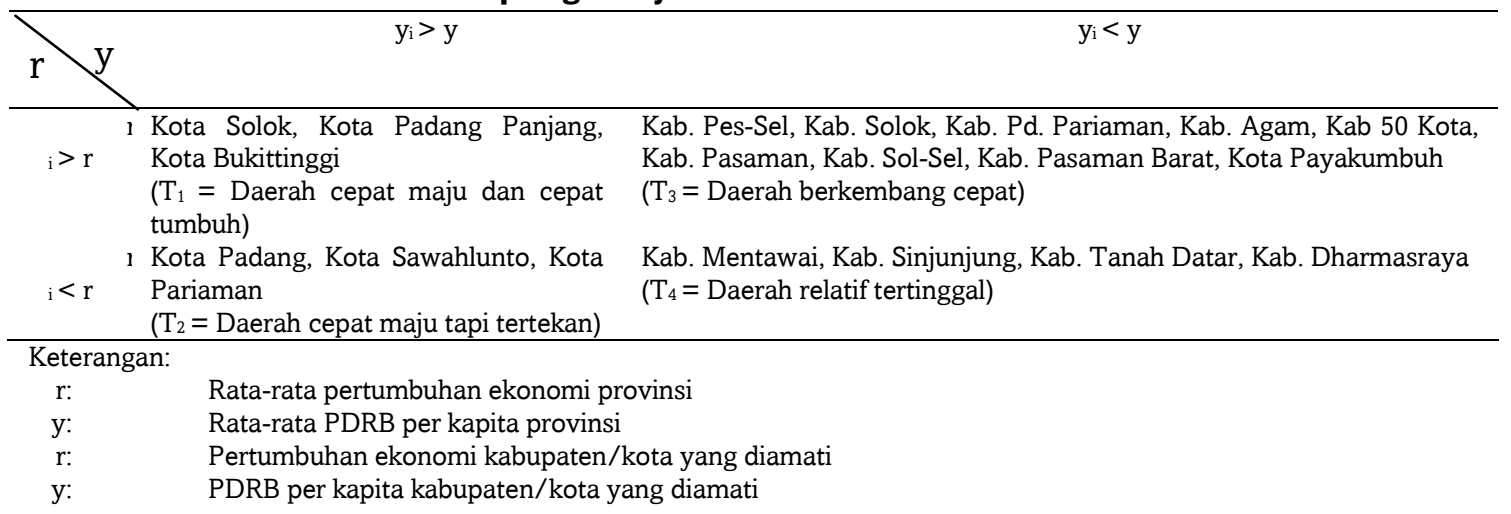

Kabupaten Kepulauan Mentawai relatif tertinggal karena kabupaten ini merupakan daerah pemekaran baru yang masih memiliki keterbatasan sarana dan prasarana pendukung aktivitas perekonomian, sedangkan Kabupaten Sijunjung disebabkan menurun drastisnya kegiatan tambang batubara sejak beberapa tahun yang lalu, karena habisnya deposit tambang batubara luar. Sedangkan tambang dalam sulit dilakukan karena memerlukan biaya operasional yang besar. Kota Padang merupakan ibukota provinsi yang sedang berkembang, sedangkan Kota Bukittinggi merupakan kota wisata dan pusat perdagangan dalam negeri yang mengalami pertumbuhan cukup pesat (Tabel 2).

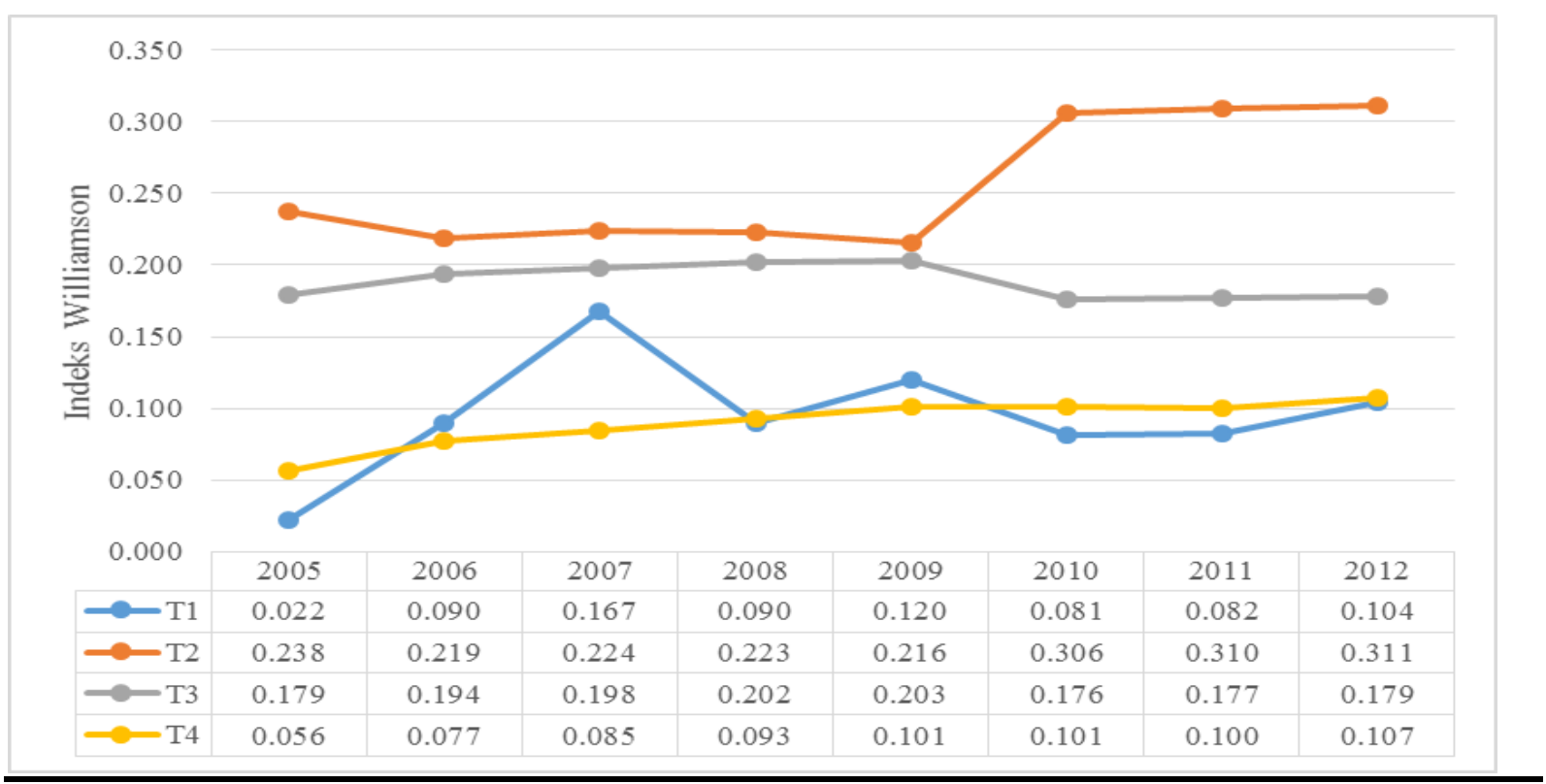

Gambar 3. Perbandingan Disparitas antar Tipologi Wilayah Provinsi Sumatera Barat 2005 - 2012 
Jika dilihat disparitas antar tipologi wilayah maka disparitas yang tertinggi berada pada Tipologi dua yaitu daerah yang relatif maju tapi tertekan yang terdiri dari Kota Padang, Kota Sawahlunto dan Kota Pariaman dengan derajat disparitas rata-rata sebesar 0.256. Kota Padang merupakan Kota yang menyumbang disparitas terbesar terhadap disparitas Provinsi Sumatera Barat. Setelah itu diikuti oleh disparitas wilayah relatif berkembang yang terdiri dari Kabupaten Pesisir Selatan, Kabupaten Solok, Kabupaten Padang Pariaman, Kabupaten Agam, Kabupaten 50 Kota, Kabupaten Pasaman, Kabupaten Solok Selatan, Kabupaten Pasaman Barat, Kota Payakumbuh dengan derajat disparitas 0.189. Diparitas wilayah maju berada pada urutan ketiga dengan rata-rata derajat disparitas sebesar 0.94. Daerah ini terdiri dari Kota Solok, Kota Padang Panjang, dan Kota Bukittinggi. Disparitas terendah dengan rata-rata derajat disparitas sebesar 0.90 berada pada daerah relatif terbelakang yang terdiri dari Kabupaten Mentawai, Kabupaten Sijunjung, Kabupaten Tanah Datar, dan Kabupaten Dharmasraya (Gambar 3). Secara keseluruhan rata-rata disparitas Sumatera Berada tahun 2005-2012 sebesar 0.394 yaitu kategori sedang (0.35 $\left.\leq \mathrm{I}_{\mathrm{w}} \leq 0.5\right)$.

Dampak PDRB per kapita, Pertumbuhan IPM dan Rasio Belanja Infrastruktur (RBI) terhadap Ketimpangan Pembangunan Antar Wilayah di Provinsi Sumatera Barat

Pada penelitian ini, analisis data panel menggunakan model Fixed Effect Model (FEM). Alasan digunakannya model ini adalah pada uji taraf nyata 1 persen Uji Chow menyatakan tolak $\mathrm{H}_{0}$ dan menerima keputusan $\mathrm{H}_{1}$ dan terdapat individual effect pada model sehingga model terbaik yang dapat digunakan adalah FEM. Hal ini juga didukung dari hasil Uji Hausman pada taraf nyata 1 persen.

Menurut uji $\mathrm{F}$ pada taraf nyata 10 persen, model dinyatakan layak untuk digunakan. Rsquare sebesar 94,21 persen artinya model ini sangat baik untuk menjelaskan data, dimana sebanyak 94,21 persen perubahan tingkat ketimpangan pembangunan di Provinsi Sumatera Barat dapat diterangkan oleh PDRB per kapita, pertumbuhan IPM dan RBI sedangkan sisanya sebanyak 5,79 persen diterangkan oleh faktor-faktor lain yang berada di luar model.

Menurut hasil uji t pada taraf nyata 10 persen semua peubah bebas secara signifikan mempengaruhi model yaitu pertumbuhan IPM, PDRB per kapita dan RBI. Pada asumsi ceteris paribus, jika pertumbuhan IPM bertambah satu satuan, maka disparitas bertambah sebesar 0.020 satuan. Sedangkan jika PDRB per kapita bertambah satu satuan pada asumsi ceteris paribus, maka disparitas sebesar 0.017 satuan. Pertambahan RBI sebanyak satu satuan akan menambah tingkat disparitas 0.585 satuan (Tabel 3).

Hasil analisis elastisitas ketiga variabel bebas menunjukan bahwa PDRB per kapita dan pertumbuhan IPM bersifat elastis, sedangkan RBI bersifat inelastis. Perubahan pada PDRB per kapita dan pertumbuhan IPM diikuti dengan perubahan yang lebih besar pada tingkat disparitas di Sumatera Barat, sedangkan perubahan RBI diikuti oleh perubahan tingkat disparitas yang lebih kecil.

Tabel 3. Hasil Estimasi Faktor Utama Yang Mempengaruhi Ketimpangan Antar Tipologi Wilayah Di Provinsi Sumatera Barat Tahun 2005 - 2012

\begin{tabular}{llll}
\hline Variabel & Koefisien & t-Stat & Prob \\
\hline Intercept & -0.043858 & -1.91423 & 0.0671 \\
YCap & $0.017031^{\star}$ & 3.360678 & 0.0025 \\
Pertumbuhan IPM & $0.020388^{\star}$ & 3.125221 & 0.0045 \\
RBI & $0.585395^{\star \star}$ & 2.787595 & 0.0100 \\
R2 & 0.942139 & & \\
F-stat & 67.84449 & & \\
Prob (F-stat) & 0.000000 & & \\
DW-stat & 1.339885 & & \\
\hline
\end{tabular}

*bersifat elatis, ${ }^{* *}$ bersifat inelastis 
Untuk mendeteksi terjadi atau tidaknya gejala multikolinearitas pada model, dilakukan pengujian dengan Uji Klein. Jika nilai korelasi antar variabel lebih tinggi daripada R-square model, maka dicurigai terdapat masalah multikolinearitas. Hasil uji ini menunjukkan korelasi antar variabel, dimana nilai korelasi antar variabel lebih kecil dibandingkan nilai R-square model, maka dapat diasumsikan bahwa model tidak memiliki masalah multikolinearitas.

Model memiliki derajat bebas $(\mathrm{db})$ sebesar 32, variabel bebas sebanyak 3. Nilai dL sebesar 1.2437 dan nilai dU sebesar 1.6505. Nilai Uji Durbin Watson pada model sebesar 1.339885. Hasil ini menyatakan bahwa model berada wilayah abu-abu sehingga tidak dapat disimpulkan apakah model mengalami masalah autokorelasi atau tidak. Meskipun demikian, pada taraf nyata 5 persen, error pada data sudah menyebar secara normal.

Masalah heteroskedastisitas sudah diatasi dengan pembobotan. Pembobotan telah mengurangi nilai error pada model yang ditandai oleh nilai sum squared residual yang mengecil (0.023854 sebelum pembobotan menjadi 0.021717 setelah pembobotan).

\section{PDRB per kapita, Pertumbuhan IPM dan RBI Provinsi Sumatera Barat berdasarkan Tipologi Wilayah}

PDRB per kapita masing-masing wilayah di Sumatera Barat memiliki variasi yang tinggi. Pada tahun 2005 PDRB per kapita yang tertinggi dimiliki oleh daerah maju tapi tertekan (T2) yaitu sebesar Rp 9.09 juta rupiah. Sampai pada tahun 2012, daerah ini memiliki angka PDRB per kapita yang tinggi dibandingkan ketiga tipologi wilayah lainnya. Daerah relatif maju tertekan merupakan daerah yang memiliki PDRB per kapita di atas rata-rata provinsi tetapi dengan pertumbuhan PDRB yang rendah dibandingkan provinsi. Sementara itu PDRB per kapita terendah berada pada wilayah relatif berkembang (T3) dimana walaupun daerah ini memiliki PDRB per kapita di bawah rata-rata provinsi, tetapi memiliki pertumbuhan PDRB yang berada di atas rata-rata provinsi. Secara umum angka PDRB per kapita setiap tipologi wilayah mengalami kenaikan setiap tahunnya.

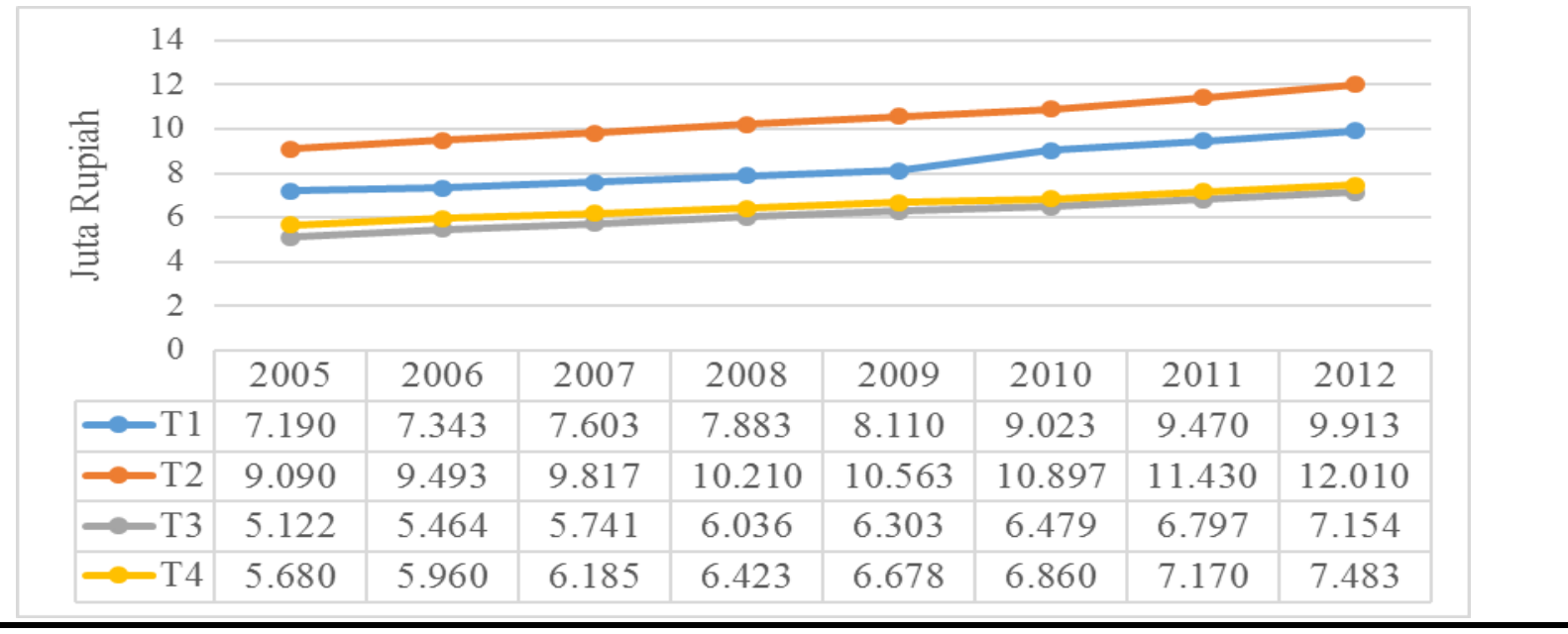

Gambar 4. Perkembangan PDRB Per Kapita Sumatera Barat Tahun 2005 - 2012 Berdasarkan Tipologi Wilayah.

Secara umum pertumbuhan IPM masing-masing tipologi wilayah di Sumatera Barat tahun 2005-2012 mengalami perlambatan (Gambar 5). Namun perlambatan ini diikuti berkurangnya variasi pertumbuhan IPM antar tipologi wilayah di Sumatera Barat. Variasi pertumbuhan yang besar hanya terjadi pada tahun 2005 dan 2006. Rata-rata pertumbuhan IPM tertinggi dimiliki oleh wilayah relatif tertinggal (T4) yaitu sebesar 0.85 diikuti oleh wilayah relatif berkembang (T3) sebesar 0.80 , daerah relatif maju tapi tertekan (T2) sebesar 0.56 dan terakhir daerah relatif maju dengan laju IPM 0.50 . 


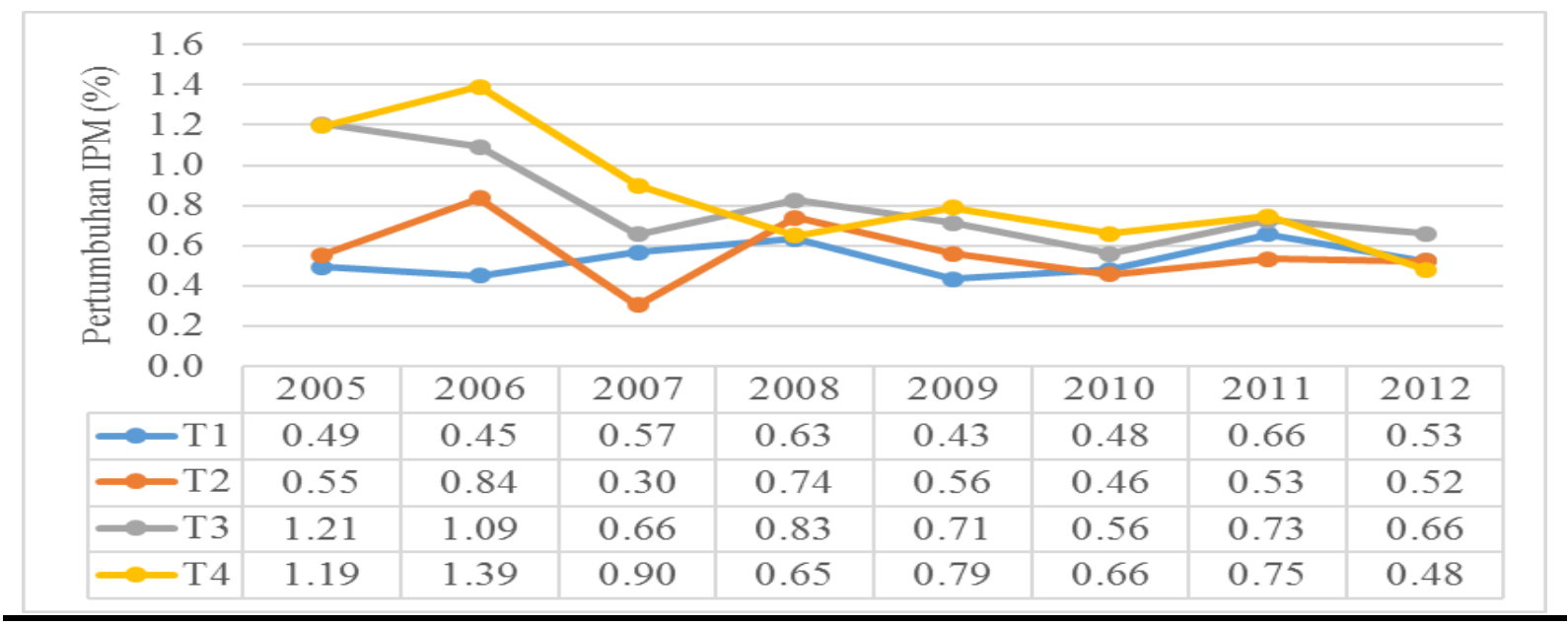

\section{Gambar 5. Perkembangan Pertumbuhan IPM Sumatera Barat tahun 2005 - 2012 berdasarkan tipologi} wilayah.

Angka IPM Sumatera Barat mengalami peningkatan dari waktu ke waktu (Gambar 4). Pada tahun 2011 angka IPM Sumatera Barat adalah 74,28 dengan rincian variabel pokok pembentuk IPM yang terdiri dari pengeluaran per kapita Rp 638,73, angka melek huruf 97,16 persen, angka harapan hidup 69,76 tahun, dan rata-rata lama sekolah 8,57 tahun. Keempat variabel utama pembentuk IPM di masing-masing tipologi memiliki besaran nilai yang proporsional dengan keadaan tipologi wilayah, artinya semakin baik tinggi tipologi wilayah maka besaran nilai pembentuk IPM juga semakin baik pula (Tabel 4). Kuncoro (2002) mengatakan bahwa tingkat melek huruf yang tinggi memberikan kontribusi positif terhadap pertumbuhan ekonomi.

Tabel 4. Variabel Utama IPM Masing-Masing Tipologi Wilayah Di Sumatera Barat Tahun 2011

\begin{tabular}{ccccc}
\hline $\begin{array}{c}\text { Wilaya } \\
\text { h }\end{array}$ & $\begin{array}{c}\text { Angka Harapan } \\
\text { Hidup (tahun) }\end{array}$ & $\begin{array}{c}\text { Angka Melek } \\
\text { Huruf (\%) }\end{array}$ & $\begin{array}{c}\text { Rata-rata lama Sekolah } \\
\text { (Tahun) }\end{array}$ & $\begin{array}{c}\text { Pengeluaran Per Kapita } \\
\text { (Ribu Rupiah) }\end{array}$ \\
\hline T1 & 70.63 & 99.25 & 10.14 & 640.986 \\
T2 & 70.56 & 98.78 & 9.58 & 630.070 \\
T3 & 68.99 & 98.23 & 8.30 & 629.946 \\
T4 & 66.55 & 95.75 & 7.78 & 626.960 \\
\hline
\end{tabular}

Sumber: BPS 2013

Perkembangan RBI Sumatera Barat tahun 2005 -2012 mengalami tren yang fluktuatif. Pada tahun 2005 RBI terbesar berada di wilayah maju dan berkembang (T1) sebesar 0.161 yang meliputi Kota Solok, Kota Padang Panjang, dan Kota Bukittinggi, namun pada tahun 2012 RBI terbesar berada di wilayah relatif tertinggal (T4) sebesar 0.118 yaitu pada wilayah Kabupaten Mentawai, Kabupaten Sijunjung, Kabupaten Tanah Datar, dan Kabupaten Dharmasraya (Gambar 6). Semakin tinggi nilai RBI suatu wilayah menujukan terjadinya peningkatan alokasi belanja infrastruktur daerah tersebut.

Belanja infrastruktur di Sumatera Barat dapat dikelompokkan menjadi belanja tanah, belanja peralatan dan mesin, belanja gedung dan bangunan, belanja jalan, irigasi dan jaringan, belanja aset tetap lainnya dan belanja aset lainnya. Pada tahun 2012 belanja infrastruktur Sumatera Barat didominasi oleh belanja gedung dan bangunan, belanja jalan, irigasi dan jaringan serta belanja peralatan dan mesin. Daerah relatif tertinggal (T4) merupakan wilayah yang mempunyai belanja terbesar terhadap pengembangan jalan, irigasi dan jaringan dibandingkan wilayah lainnya. Hal ini mengindakasikan adanya upaya dari daerah tertinggal untuk memperlancar akses guna memicu pertumbuhan dan pemerataan ekonomi dan mengejar ketertinggalan dari wilayah lain (Gambar 7). 


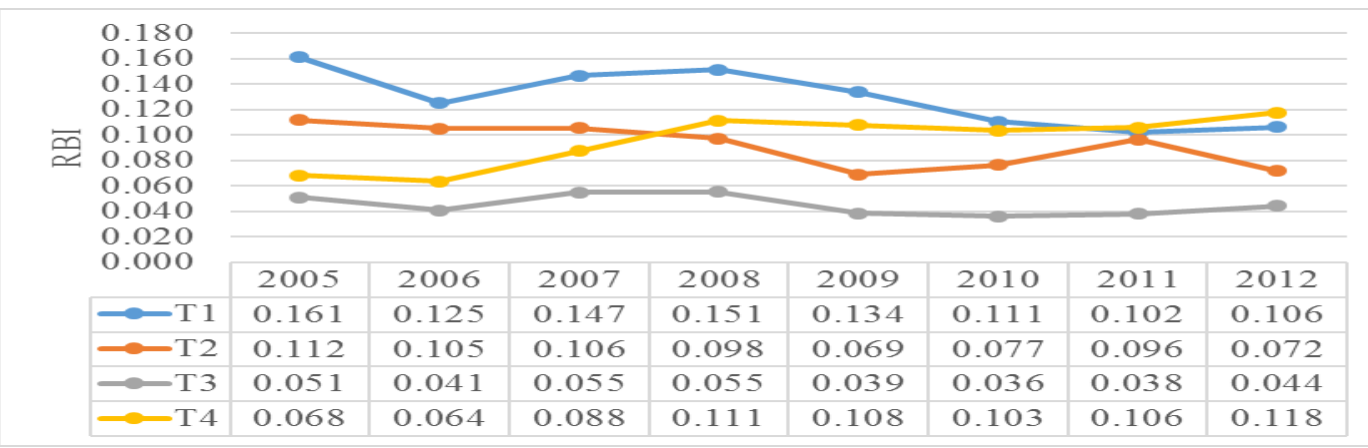

Gambar 6. Perkembangan RBI Sumatera Barat Tahun 2005 - 2012 Berdasarkan Tipologi Wilayah.

Hasil studi Priyarsono (2014) juga menunjukan bahwa umumnya infrastruktur berdampak positif terhadap perekonomian, dimana wilayah maju cenderung responsif terhadap infrastruktur ekonomi seperti jalan dan irigasi sedangkan wilayah kurang maju responsif terhadap infrastruktur sosial seperti sekolah dan rumah sakit. Selanjutnya, studi Purnamadewi (2010) menyimpulkan bahwa dampak pembangunan infrastruktur (jalan dan irigasi) yang bias ke industri non pertanian, kelompok sektor jasa dan kelompok sektor lain (perdagangan, hotel dan restaurant, transportasi dan komunikasi) mengindikasikan bahwa pembangunan infrastruktur jalan masih bias ke wilayah perkotaan karena sektor-sektor tersebut lebih terpusat di perkotaan, sehingga untuk menurunkan tingkat disparitas antar wilayah, maka pembangunan infratruktur jalan dan irigasi harus diprioritaskan ke wilayah-wilayah dengan pendapatan perkapita yang relatif rendah atau wilayah sentra produksi pertanian.

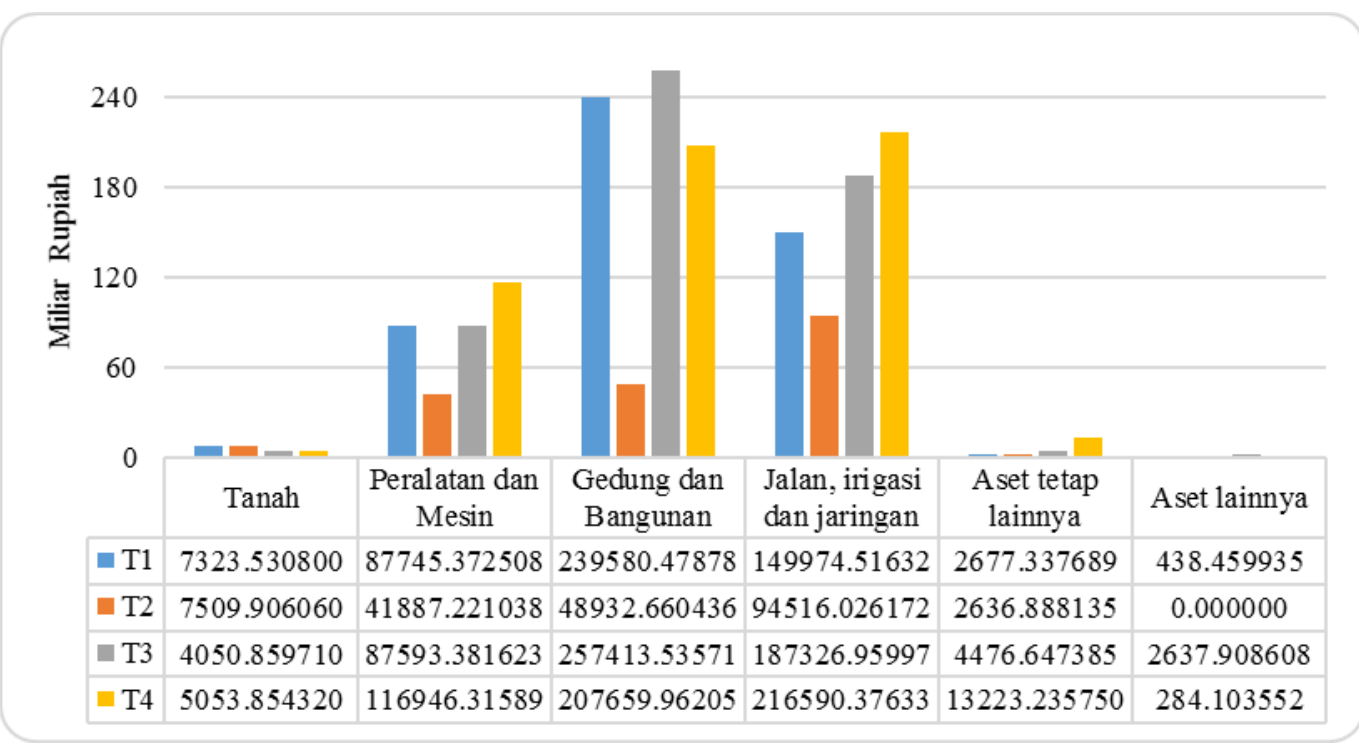

\section{Gambar 7. Rincian Belanja Infrastruktur Sumatera Barat Tahun 2012 Berdasarkan Tipologi Wilayah}

Infrastruktur jalan merupakan salah satu infrastruktur pengangkutan yang berperan dalam merangsang pertumbuhan ekonomi karena ketersediaan jalan akan meminimalkan modal komplementer dalam upaya mengefisienkan proses produksi dan distribusi. Pembangunan prasarana jalan turut akan meningkatkan pertumbuhan wilayah-wilayah baru dengan meningkatnya volume lalu lintas. Sebaiknya prasarana jalan yang buruk dan rusak akan menghambat alokasi sumber daya, pengembangan industri, pendistribusian faktor produksi, barang dan jasa, yang pada akhirnya akan memengaruhi pendapatan. Ikhsan (2004) mengemukakan bahwa jalan raya akan memengaruhi biaya variabel dan biaya tetap. Jika 
infrastruktur harus dibangun sendiri oleh sektor swasta, maka biaya akan meningkat secara signifikan dan menyebabkan cost of entry untuk suatu kegiatan ekonomi menjadi sangat mahal sehingga kegiatan-kegiatan ekonomi yang sebetulnya secara potensial mempunyai keunggulan komparatif menjadi tidak bisa terealisasikan karena tidak tersedianya infrastruktur.

\section{Kesimpulan}

Simpulan dari penelitian ini adalah: (1) perkembangan ketimpangan pembangunan antar wilayah di Provinsi Sumatera Barat Barat di era otonomi daerah semakin meningkat yang berada pada kategori sedang; (2) secara simultan dan parsial kenaikan PDRB per kapita, pertumbuhan IPM dan rasio belanja infrastruktur memicu kenaikan tingkat ketimpangan antar wilayah di Provinsi Sumatera Barat. Namun hasil analisis elastistas menunjukkan bahwa hanya perubahan PDRB per kapita dan pertumbuhan IPM diikuti oleh perubahan yang lebih besar pada tingkat disparitas (elastis) sementara perubahan RBI diikiuti oleh perubahan yang lebih kecil pada tingkat disparitas (inelastis).

Pemerintah hendaknya mendorong bentuk-bentuk pertumbuhan ekonomi yang lebih berkualitas dalam menciptakan keberimbangan struktur (diversitas) ekonomi dalam wilayah dan keberimbangan antar wilayah. Hal ini dapat dilakukan dengan meningkatkan sektor-sektor primer yang cenderung memicu pemerataan serta meningkatkan pembangunan manusia dan pembangunan infrastuktur/fasilitas pelayanan publik dan mendorong peningkatkan aksesibilitas dalam upaya memajukan tingkat perkembangan pembangunan wilayah. PDRB per kapita yang rendah dapat ditingkatkan dengan pertumbuhan ekonomi melalui sektor potensial seperti pertanian. Pemerintah harus mendorong dampak penyebaran dengan peningkatan kualitas belanja infrastruktur dan bagi daerah relatif tertinggal perlu big push dengan memanfaatkan jaringan kerjasama antar daerah serta investasi pada sektor potensial yang diikuti insentif, iklim investasi dan regulasi yang ramah.

\section{Daftar Pustaka}

Ardani A. 1992. Analisys of Regional Growth and Disparity: The Impact Analisys of the Inpres Project on Indonesian Development. [Ph.D Thesis]. University of Pensylvania, Pensylvania.

Kuncoro M, Aswandi H. 2002. Evaluasi Penetapan Kawasan Andalan: Studi Empiris di Kalimantan Selatan 1993-1999. Jurnal Ekonomi dan Bisnis Indonesia 17(1): 27-45.

Bose NJ. Holman and Neanidis K. 2005. The Optimal Public Expenditure Financing Policy: Does the Level of Economic Development Matter? Centre for Growth and Business Cycle Research 05(7): 1-4.

[BPS, Dinas Pengelolaan Keuangan Daerah Provinsi Sumatera Barat]. 2013. Realisasi Belanja Pemerintah Derah Provinsi Sumatera Barat Tahun 2012. Badan Pusat Statistik Provinsi Sumatera Barat, Padang.

[BPS] Badan Pusat Statistik. 2012. Indeks Pembangunan Manusia tahun 2009-2012. Badan Pusat Statistik, Jakarta.

[BPS] Badan Pusat Statistik. 2011. Produk Domestik Regional Bruto dan PDRB Perkapita menurut Kabupaten/Kota ADHK 2000 tahun 2009-2010. Badan Pusat Statistik Provinsi Sumatera Barat, Padang.

Djojohadikusumo, S. 1994. Perkembangan Pemikiran Ekonomi: Dasar Teori Ekonomi Pertumbuhan dan Ekonomi Pembangunan. LP3ES, Jakarta.

Ikhsan. 2004. Hubungan Antara Infrastruktur dengan Pertumbuhan Ekonomi dan Pembangunan. LPEM, Jakarta.

[KPDT] Kementrian Pembangunan Daerah Tertinggal. 2013. Penyebaran Daerah Tertinggal di Indonesia. KPDT RI, Jakarta.

Kuncoro, M. 2004. Otonomi dan Pembangunan Daerah: Reformasi, Perencanaan, Strategi dan Peluang. Erlangga, Jakarta.

Priyarsono, DS. 2014. Beberapa Masalah dan Kebijakan Publik tentang Infrastruktur: Tinjuan dari Perspektif Ilmu Ekonomi. IPB Press, Bogor.

Purnamadewi, YL. 2010. Dampak Perubahan Produktivitas Sektoral Berbasis Investasi Terhadap Disparitas Ekonomi Antar Wilayah di Indonesia. [Disertasi]. Sekolah Pascasarjana IPB, Bogor.

Sjafrizal. 1997. Pertumbuhan Ekonomi dan Ketimpangan Regional Wilayah Indonesia Bagian Barat. Prisma LP3ES, 26 (3): 27-38.

Sjafrizal. 2008. Ekonomi Regional: Teori dan Aplikasi. Baduose Media, Padang. 